\title{
JUNIOR-SENIOR HIGH SCHOOL BASED ON PESANTREN BOARDING SYSTEM
}

\author{
Abdul Rohman \\ Faculty of Tarbiyah And Teacher Training of IAIN Walisongo Semarang. \\ Jl. Prof. Dr. Hamka KM 1 Ngaliyan Semarang 50185 \\ E-mail: abdulrohman@walisongo.ac.id
}

\begin{abstract}
The study is aimed to uncover that a boarding system in junior-senior high school (SMP-SMA) Semesta Billingual Boarding School (BBS) Semarang adopted the pesantren style. This is evidenced by the fact that, like pesantren, the typical of boarding school in BBS Semarang puts more emphasis on strengthening the affective (akbläq) aspects, because of; 1) the curriculum of all subjects in school mutually integrated, 2) the curriculum design by the development of self-habituation, 3) design through creating climate and culture, 4) constitute the hidden curriculum, 5) more "mutually adaptive" and dominated by transmission model rather than transaction and transformation model, 6) can be used as an eclectic systems, between constructivist and non-constructivist, the social and personal model, the information and processing model, the humanism and behavioral oriented. The main purpose of the schools adopts the boarding school system to maintain and improve the quality of learners morals. However by adopting such system, learners can be monitored for almost 24 hours because they had been living in the college. Thus, adopting a boarding school system can be a solution to overcome and reduce morale among students dekandensi Indonesia and even in other countries.
\end{abstract}

Keywords: Pesantren, Billingual, Junior-Senior High School.

\begin{abstract}
ABSTRAK
Penelitian ini bertujuan mengungkap bahwa sistem pendidikan SMP-SMA Billingual Semesta (BBS) Semarang mengadopsi gaya pesantren. Hal ini dibuktikan oleh fakta bahwa tipikal dari Bilingual Boarding School (BBS) Semarang menekankan pada penguatan aspek afektif (akblaq), yang didukung dengan; 1) terintegrasinya desain kurikulum pada semua mata pelajaran di sekolah, 2) desain pengembangan diri melalui pembiasaan, 3) didesain melalui penciptaan iklim dan budaya, 4) menerapkan kurikulum tersembunyi, 5) lebih "adaptif "dan didominasi oleh model transmisi daripada transaksi dan transformasi, 6) dapat digunakan sebagai sistem pendidikan eklektik, baik bersifat konstruktivis maupun non-konstruktivis, model sosial maupun pribadi, model informatif maupun model proses, bumanisme maupun yang berorientasi pada behaviorisme. Tujuan utama sekolah ini mengadopsi sistem pondok pesantren dalam rangka mempertahankan dan meningkatkan kualitas akblak peserta didik. Dengan mengadopsi sistem pesantren, peserta didik dapat dipantau selama hampir 24 jam karena mereka seperti tinggal di pondok pesantren.
\end{abstract}


Dengan demikian, bagi sekolah yang mengadopsi sistem pesantren dapat menjadi solusi untuk mengatasi dan mengurangi dekadensi akblak di kalangan siswa Indonesia dan babkan di negara lain].

Kata Kunci: Pesantren, Billingual, SMP-SMA.

\section{INTRODUCTION}

Syauqi (n.d. p. 166) argues that the existence of a nation is based on the kindness of its morality (akbläq), and when morality was damaged, the nation is also destroyed. On the urgent morality, Langgulung (1989, p. 373) states that the formation of character was the soul of education; also al-Abrasy (1963, p. 59) asserts that the most important purpose of education was the formation of character (akbläq). There are several terms that often lead to different perceptions, namely: moral, akbläq, ethics, character. Moral is a general term, while akbläq is the Islamic terminology, so Syukur (2000, p. 12) mentions the term akbläq with Islamic morality. Akbläq refers to al-Quran and al-Sunnah, while the moral comes from human thought and customs. While discussing the principles of good-bad, what should be done and what should be left, it is called "moral philosophy", which Mudhoffir (1996, p. 19) called it as ethics. Ethics is a branch of philosophy that talking about values. The values consist of a akbläq, morals, or character in its philosophical formulation aided by ethical considerations. Value is something that is instilled in a person, so that it can form the character. The characterized people are people in whom already internalized with values, so they have their own characteristics, which distinguish between one another. Akbläq is an act that is done repeatedly, easily without the need for thought or consideration for doing so (al-Ghazali, n.d [III], p. 56; Miskawayh, 1934, p. 40; Amin, 1967, 50). In line with them, Martin Luther King, Jr. also stated that "intelligence plus character-that is the goal of real education" (Dolph \& Lycan, 2008, p. 13). Lickona (1992, p. 6) also said that "education has had two great goals: to help young people become smart and to help them become good".

Good education has to develop integratedly these two human's aspects: cognitive and affective. Lickona (1992, p. 6) stated that morality was the foundation for the establishment of a democracy. Smart and good are two different things. Intelligent society who is based on the good morality, would use their intelligence to help others, and to build a better world. In contrast, intelligence (smart) without morality (good) often causes harm. "Goodness without knowledge is weak and feeble, yet knowledge without goodness is dangerous, and that both united form the noblest character" (Davidson \& Lickona, 2007). 
Discussion of the character (akbläq) can not be separated from a discussion about value. Historically, values have long played an important role since Plato's era in which he put the idea of 'good' at the top of the hierarchy of values (Hufad \& Sauri, 2010, p. 50). Even according to Carr (1991, p. 23), value of education literally was also found in the teachings of Socrates (469-399 BC) and Plato (428-347 BC). Both believed that moral value is a science that can be taught (thus virtue is knowledge and teachable). Their successors are Aristotle (384-322 BC) who was Plato's student, but he did not just take for granted the teachings of Plato. According to Arthur (2003, p. 30), one of the differences between Plato and Aristoles is related to habituation. Plato argued that someone who knows the goodness surely do good, while Aristotle argued that knowing is not enough kindness, humans need to be habituated to do good. Lickona (1992, p. 6) stated that the "wise societies since the time of Plato have made moral education as a deliberate aim of schooling. Their aims of education were for character, intellect, decency, literacy, virtue and knowledge".

In the Indonesian context, education leaders such as RA Kartini, Ki Hajar Dewantara, Soekarno, Mohammad Hatta, Tan Malaka, Mohammad Nasir, Mohammad Syafe'i have asserted the urgency of character education (Supriyatna, 2010, p. 489). However, the effort to implement the character education seems not to have worked well yet. This can be seen in the reality stated earlier which shows that Indonesia is still experiencing the issue of morality such as the widespread cases of drug abuse, promiscuity, criminality, violence; corruption, collusion and nepotism $(K K N)$ and others. Politeness, friendly nature, tolerant, humble, helpful, and social solidarity, which have become national identity for centuries no longer exist among Indonesians (Zubaedi, 2009, p. v). Indonesia was experiencing a multidimensional crisis such as that Indonesian society has become a corrupt society, ordinary people are fragile and disoriented, easily swayed and without orientation, demonstrating anti-social, anti-establishment, violent, and loss of balance between reason and emotion (Prabowo \& Sidi, 2010, p. 166).

The survey of PERC (Political and Economic Risk Consultancy) conducted in 2002-2006 stated that scores of Indonesian corruption reached the highest position in Asia (Muslich, 2011, p. 5-6). Similarly, the increasing use of violence against other people of different beliefs, different tribes, different classes, the chaotic traffic, the environmental damage (Zubaedi, 2011, p. 1) is another indicator of the problem of morality. The PERC survey also showed that Indonesia's education system ranks was the worst in Asia. South Korea was considered to have the best education system, followed by Singapore, Japan, Taiwan, India, China, Malaysia. The report of UNDP (United Nations Development Programme) in 2004 and 2005 stated that the 
Human Development Index (HDI) Indonesia also dropped. In 2004, Indonesia ranks 111 out of 175, occupying a position under poor countries like Kyrgyzstan (110), Equatorial Guinea (109) and Algeria (108); whereas in 2005 were in position 110 out of 177 countries. This is in contrast withneighboring countries which have much better rank, namely Singapore (25), Brunei (33), Malaysia (58), Thailand (76), Philippines (83). Indonesia only be one level above Vietnam (112), Mianmar (112), some level of Cambodia (130), and Laos (132) (Muslich, 2011, p. 2).

This low morality occurs because each individual's sense of discipline and responsibility is low. Discipline which is defined by Aqib and Sujak (2011, p. 6) as "an attitude and orderly behavior and compliance with the various rules and regulations", is no longer owned by individuals. Shochib (2010, p. v) also stated that the rampant violation of moral values and lack of discipline embodies. It can be stated that they still have a little accountability. Responsibility which is defined by Aqib and Sujak (2011, p. 6) as the "ownership attitude and behavior to carry out their duties and obligations as they should do for themselves, society, the environment, the state, Almighty God", is no longer being owned by Indonesian individuals. When these two values (discipline and responsibility) are embedded in a person, the attitude and behavior of deviant, immoral is not going to happen to the individual. A disciplined person is the person who has the attitude, conducts orderly and complies with various rules and regulations. Individuals deviate from different variantsbecause they do not have attitude and behavior to carry out their duties and obligations and to comply with various rules and regulations. Responsible person is a person who has attitude and behavior to carry out their duties and obligations. Shortly, it occurs because they do not yet have a personal responsibility and good discipline.

Lickona (2013, p. 63) stated that the value of respect and responsibility are central values and will have consequences and implications for other ones ; the other values essentially derived from these two values. Research by Rest (1974), Edwards (1981) as presented Sjarkawi (2011, p. 41) asserted that a person's resposibility is positively correlated with the level of moral consideration. The higher the level of moral judgment they have, the greater levels of socialization and responsibility they have. Conversely, the lower the levels of moral judgment they have, the worse the socialization and accountability they will have. Therefore, responsibility and discipline must be owned by any individual to make sure that moral violations are not happening to him.

Japan, Taiwan and China (Supriadi, 1998, p. 333), (three countries in Asia) were classified as a developed country, because they had the attitude and behavior responsibility and discipline. They were very concerned with 
the education in development policy; even in some ways, education in the three countries surpassed education in the USA. In the 1970s, the Chinese State could be said to be no better off than Indonesia. But in less than 30 years, with high discipline, hard work, China has managed to rise to move its national production machines. Chinese culture was reflected in the success of their discipline in pressing problem of corruption among bureaucrats substantially. Culture of hard work in the spirit of the Chinese people can be seen in their willingness to work seven days a week in order to achieve excellence and glory of theircountry. Now, China has not only become the largest exporting country, but also a growing number of Chinese export production contain high technology and high technology (Muslich, 2011, p. 5). According to Megawangi (2007, p. 20), China had successfully implemented a character education to the nation. China had carved out a moral nation through a process of knowing the good, loving the good and the acting good. Character education carried out by China, according to Prabowo \& Sidi (2010, p. 167) was an educational process that involves aspects of cognitive, emotional and physical so that noble and lofty characterbecomes the habit of minds, hearts and hands.

Talking morality (akbläq) or value, if it is viewed in the perspective of Bloom that classifies education into three domains, namely cognitive, affective and psychomotor, it relates to affective domain in which Bloom et al. (1976, p. 36) sees the affective domain including interest, attitude, appreciation, value. Similarly, in the view of Ki Hajar Dewantara, it relates to character in which Dewantara (1962, p. 14) states that education is "to bring forward character, intellect and the body of the child".

Therefore, if the education system in Indonesia is willing to achieve the goal of a comprehensive education, the three domains must be addressed in proportional level of both design and implementation. The Act of s. 20. 2003, Chapter II, Article 3 explicitly formulate that the national education goals is "...to develop students' potentials in order to become a man who is faithful and devoted to God Almighty, morals precious, healthy, knowledgeable, skilled, creative, independent, and become democratic and accountable citizens". This formulated objective becomes the entry point of all formulas of institutional goals of all types, lines and levels of education in Indonesia, when viewed in the perspective of Bloom et al. or Ki Hajar Dewantara, the formulation of these objectives has included a complete taxonomic domain.

However, the reality shows that the implementation of education in Indonesia has not given the appreciation in proportional domain (Aqib \& Sujak, 2011, p. 6; Dewantara, 1962, p. 25; Mas'ud, 2002, p. 212). Education is not managed to build good human character because the educational value is 
not applied effectively (Sjarkawi, 2011, p. 37; Prabowo \& Sidi, 2010, p. 166; Azra, 2002, p. 178; Mas'ud, 2002, p. 212; Freire, 2002, p. 190; Sanjaya, 2008, p. 1; Buchori, 1992, p. 2; Nasution, 1995, p. 3; Muhaimin, 2009, p. 23-25; Abdullah, 1998, p. 5).

Affective domain which has an important role on the individuals has often been overlooked. This, according to Hadjar (2006, p. 5), is because: (1) the affective domain is difficult to define and measure, (2) lack of evaluation tools to measure it, (3) reluctance to put a value on the affective aspects as they relate to issues of validity and reliability, (4) difficulty in determining the standards of behavior that reflects the affective domain, (5) at least direct consequences which reflects affective behavior.

Theoretically, the formation of moral character or internalization of affective domain (including the value of discipline and responsibility) is not enough to just be taught through cognition alone. Cognition according to Bloom et al. (1976, p. 20) indeed have contributed to the formation of affection, but it's a small contribution. Planting affective aspects requires habituation. When a practice has been accustomed to do, due to the habituation, then it will become a habit and then will be hooked, and in time become a tradition that is hard to leave it (Azizy, 2002, p. 146).

Habituation in the cultivation of the values requires modelling in order to be effective (Zaenuddin et al., 1991, p. 106; Azizy, 2002, p. 146; Dewantara, 1962, p. 28; Noddings, 2010). Modelling becomes an important aspect, especially for children, to get the good example. The deed of teachers actually always considered by every student. Behavior and even the teachers teaching style would be difficult to remove in the memory of every student. Moreover, the character of the teacher is also always in binoculars and once used as a mirror of his students. The habituation is an effective method in the internalization of values.

Habituation and modelling for the 'good stuff' takes time. The cultivation of values requires habituation and ideals that automatically requires a long time to arrive at the 'characterization', in which value can become character (personality) of a person. Noddings (2010) in his research found some ways to moral cultivation: modeling, dialogue, practice, and confirmation. Value or character can be implanted effectively when it is undertaken by using integrative approach (Nurchaili, 2010, p. 237; Creasy, 2010, p. 6; Oladipo, 2009, p. 149; Hasan, 2010,p. 15; Sjarkawi, 2011, p. 42; Kohlberg, 1977, p. 135; Goods, 1945, p. 11; Durkeim, 1990, p. 7; Dewantara, 1962, p. 369).

With integrative approach, in the context of learning in school, character education is positioned as the mission of each subject, carried out through daily learning which has been running in schools, not being taught in 
special subjects (Nurchaili, 2010, p. 237). Education requires an ongoing process, which is undertaken through a variety of subjects in the curriculum (citizenship, history, geography, economics, sociology, anthropology, Indonesian, social studies, science, math, religion, physical education and sports, art, skill). Even further, character education can be integrated in the activities of intra- and co-curicular. Planning and implementing should be carried out jointly by the principal, teachers, and staff (counselors) as a community of educators who applied to the curriculum through: (1) selfdevelopment programs, (2) integration into all subjects, (3) integration into co-curiculer and extra-curricular activities, and (4) habituation (Hasan, 2010, p. 15).

Shaver as quoted by Sjarkawi (2011, p. 42) argued that the school is an educational institution that is responsible for improving thinking skills and proficiency in setting a decision to act or not to act. Kohlberg (1977, p. 135) stated that the purpose of education is basically to develop the intellectual and moral capabilities. Goods (1945, p. 11) stated that moral education can be done formally or incidentally, both at school and in the home environment. Durkeim (1990, p. 7) emphasized that moral education was transferred from the home environment to the school because the school has a special task in terms of morale. Sjarkawi (2011, p. 42-44) stated that "school should be more sensitive to the problem's of inability to think and behave morally. Almost all crises, failures and the emergence of behaviors of undesirable people are always being questioned and linked with the implementation of moral education in schools". What Sjarkawi reported (2011, p. 44-45) is in line with the studies of Rosjidan (1990), Soedayat (1993), Moerdiati (1993), Maramis (1990), Irsan (1993), Soenarwan (1993), Lopa (1993), Jamaladin (1994), Rivai (1994).

Sjarkawi (2011, p. 44) based on Rosjidan's research (1990) suggested that the presence of factors causing negative behaviors committed by teens is due to lack of effective moral education in schools, therefore moral education in schools should be improved and intensified. In addition, having based on research conducted by Santoso (1991), Sjarkawi (2011, p. 45) asserted that the moral depravity of affairs can not be repaired only by an appeal, speeches, sermons, plays, seminars, work meetings, and various forms of other similar efforts, but by moral education atschools. Moral education is part of the affected environment, intentionally designed to develop and change the way of thinking and acting in a moral situation. Moral education should be undertaken at school and outside of school. Everything programmed in the school aims to help children think about issues of right and wrong, good and bad, expect social improvement and help students to be able to behave based on moral values. 
In addition, an integrated moral education should also be reflected in the implementation, not only being carried out by school institutions (formal institution), but also being interrelated with education at home (informal institutions) and public (non-formal educational institutions) (Creasy, 2010, p. 6; Oladipo, 2009, p. 149). Dewantara (1962, p. 369) calls these three educational system with the name 'among' system, which is implemented through the 'Tri Pusat Pendidikan'. In Act of National Education System s. 20.2003, chapter VI stated that education was held in complementary and enriching through formal education, non-formal and informal (Article 13).

Basically, education which involves interaction between educators with students in an effort to help learners master the objectives of education, is the responsibility of parents (Sukmadinata, 2011, p. 2). The parents who have full responsibility for educating their children, are supposed to prepare their children for the future with a set of knowledges, skills, attitudes necessary in life and later life. Parents should teach, train and educate their children so that they grow and develop into a matured person. In a family environment, educational interaction occurs between parents as educators and as learners. According to Dewantara (1962, p. 374), actually education is the responsibility of the family. However, it is often the case that the interaction in a family run without a written plan; in addition, parents often do not have a clear and detailed plan as to where their children will be directed, in what way they will be educated, and without educational content. Educational interaction between parents and their children are often not realized. Parents also become educators often without formally prepared. They become educators because of their status as a father and mother, although they may be in fact not ready for the task. From this condition, then they need a formal education institutions. The parents hand over their children to the school institution whose role is as a formal educational institutions conducted by teachers who are formally prepared for the task.

Unlike the family education, school education is the formal process, in which teachers who portray themselves as educators have been prepared by the teacher education institutions (Sukmadinata, 2011, p. 3). They have been nurtured to have a personality as educators. They are also raised and given credence by the public to be a teacher. They carry out their duties as educators to plan and prepare education. They teach children with clear objectives, arrange materials in a systematic and detailed way, select and design means and method carefully. At school, teachers interact with children in a planned and conscious educational environment. Sukmadinata (2011, p. 2-3) stated that there are several advantages of formal education compared to family education (informal), namely: (1) formal education in schools has a broader scope of educational content, not only with respect to the moral 
aspects of coaching but also knowledge and skills, (2) education in schools can provide higher, wider and deeper knowledge, (3) with a formal and written curriculum, education in schools conducted in a planned andsystematic way.

During its development, formal education institutions which had become a footstool for parents to educatetheir children to become a matured person for the future, turned out to have different variants. There is a school institution which emphasizes on thestudents' personal balance of all aspects ofcognitive, affective and psychomotoric domain, while others put more emphasis on cognitive domain. Even now there is a phenomenon that education is mostly dominated by the cognitive aspects, and lack of attention on the psychomotor domain and affective domains (Sjarkawi, 2011, p. 37; Prabowo \& Sidi, 2010, p. 166; Azra, 2002, p. 178; Mas'ud, 2002, p. 212; Freire, 2002, p. 190; Sanjaya, 2008, p. 1; Buchori, 1992, p. 2; Nasution, 1995, p. 3; Muhaimin, 2009, p. 23; Fuaduddin \& Bisri, 1999, p. 2; Abdullah, 1998, p. 5).

Educationis now mostly direct students to be smart than to have good character, which should both be achieved simultaneously. Lickona (1992, p. 6) stated that "down through history's countries all over the world, education has had two great goals: to help young people become smart and to help them become good". Therefore, ideally, educational institutions perform the function of developing intellectual aspect and internalizing values in a balanced and simultaneous way, which experts called it with different terms, namely: intellligence plus character (Martin Luther King, 1948); smart and good (Lickona, 1992); cognitive, affective and psychomotor (Benjamin S. Bloom et al, 1976); character, mind and body (Ki Hajar Dewantara, 1962); thinking, acting, feeling (Gable, 1986).

There are two formats of such Islamic educational institutions. For example, one is in the form of integrated schools, such as TKIT (Islamic Integrated Kindergarten), SDIT (Islamic Integrated Elementary School), SMPIT (Islamic Integrated Junior High School), SMAIT (Islamic Integrated High School) held with a full day. Another one uses the boarding system, i.e. a system of 'school in' in which the students live in a certain area (staying home) that is integrated with the school. Boarding school system is actually a system that combines the functions of a family where the parents instill values to their children while school puts more emphasis on the intellectual, and the functioning of society in which children typically perform exploration and stabilization of values. Azra (2005, p. xxiii) states that boarding system is actually one of the basic characteristics of the pesantren education system. Kamus Besar Bahasa Indonesia defines pesantren as "boarding where students live in or places where students learn the Koran and so on" 
(Alwi, 2005, p. 867). This residence, which Mastuhu called it as 'cottage' (in Aly, 2011, p. 153), is built in the complex of pesantren (Damopolii, 2011, p. 67). Thus, the boarding school is a school which all of its students live in a dormitory managed integratedly with the school.

Based on above background, this study aims to find out about the philosophyof curriculum, the design, and the implementation of curriculum in internalizing akbläq values (i.e. disciplineand responsibility) in SMP-SMA Semesta BBS Semarang. This study will also try to see how the akbläq values are internalized in children at educational institutions that implement the boarding school model, an institution that provides facilities to all students living in a the integrated system between schools and boarding. The values that will be seen in context of implementation are discipline and responsibility, two values as Lickona $(2013$, p. 63) stated are the foundation of the other values. He stated that when these two values are already embedded in the child, the other values will follow then. The hadith (Muhammadan tradition) also states that "every one is a leader, and every leader should be responsible for all of their leadership".

\section{FINDINGS AND ANALYSIS}

The philosophy of curriculum in SMP-SMA Semesta BBS is: "to be the center of education in preparing children with Germany-oriented brain, Mecca-oriented heart and based on Indonesian culture". It is also confirmed with the desire of the Semesta Foundation, i.e. "we want our students become successful not only academically in their lessons, but also improve their character and be useful people for Indonesia". SMP-SMA Semesta BBS which uses boarding system designes its curriculum integratedly between school and boarding for 24 hours a day learning activitiy. At the boarding school, the curriculum is designed as pesantren, either in written curriculum and hidden curriculum. Initially, the Semesta Foundation was eager to design a modern pesantren. However, based on the ulama's suggestions, the foundation changed the type of educational system from pesantren to 'boarding-based school'.

Internalization of akbläq values i.e. discipline and responsibility in SMP-SMA Semesta BBS implemented the form of pesantren boarding system, broadly was grouped in several forms, namely: 1) establishing a climate and culture, 2) learning in the classroom, 3) habituation outside the classroom, 4) extra curricular activities, 5) counseling (rebberlik and sobbet), 6) camping.

Activities in the Semesta are scheduled throughout the 24 hours a day, and implemented consistently in all situations for 24 hours as well. The climate is designed to instill values to children. Habituation programs also undertaken consistently in order to create the climate. To support 
habituation, the example (modelling) given in the whole time by all elements of the institution: the school principal, teachers, staff and dorm supervisor. In addition, it is also supported by a set of rules in the form of 'discipline system', a shared commitment which is transparent for all school community to implement. The participation or exclusion of students to discipline system in the school or boarding, accompanied by a set of rules, called 'offense points' for noncompliance and 'bonus points' for thededicated students.

Substantially, the majority of class room teaching of SMP-SMA Semesta BBS provides 'instructional effects' on cognitive and psychomotor learning outcomes. Only a few subjects that provides 'instructional effect' on aspects of values, such as Islamic Religious Education (Pendidikan Agama Islam) subjects, civics and social studies; while all other subjects taken by all students gives thema good 'nurturant effect' through learning strategies, habituation, exemplary, and he creation of value-laden culture. All teachers also have a commitment to internalize values to students.

All students have to do a number of activities to support habituation outside the classroom such as the five daily prayers in congregation, the activities of eating, reading the Quran, etut (learning together), a flag ceremony, commemoration days of religion, the subject matter of week, and others. As writtenin the daily routine schedule, school schedule runs starting from 07: 30 a.m. to 15: $00 \mathrm{pm}$.

Extracurricular is an implementation of self-development program launched by the structure of the curriculum. Its activities have clear timetable, but without coach and without assesstment put into the reportbook. While clubs are the types of activities that students are engaged in a field, the activities are set by the board itself. Clubs are under the guidance of teachers and coaches dormitory. In these clubs, there is no system of assessment. In junior-high school of the Semesta BBS, extra curricular provided in the open-close system. This means if there are students who are interested in the extra-curricular activities, the program will be run.

The counselling is performed routinely by both teachers and students. For students, the activities carried out two times a week i.e. on Wednesday and Friday and guided by each class-teacher and dormitory supervisors. The counselling is given to internalize the values that transcend the boundaries of religion, ethnicity, culture, such as responsibility, discipline, perseverance, patience, and so on. In addition, there is also study session (sobbet) in accordance with their respective religions. Forteachers, counselling is given by teachers themselves exchangebly.

Camping aims to improve the spirituality of teachers and students, improve students' reading craze, deepen faith, and discuss various topics 
among students. The program is also intended to improve positive student interaction of different religions.

Activities that cater for both students and teachers are conducted three times a year, in the end of the semester (July and December) and in the month of Ramadan for seven days. For students, camping implemented with assistance by the teacher and ormitory supervisors. For classes IX and XII, camping activities held in the campus of the Semesta is directed to the preparation of the national exams (Ujian Bersama). While other classes (Classes VII, VIII, X, XI) held in accordance with the agreement of each class such as in Central Java, East Java and West Java, some even in Turkey.

\section{ANALYSIS}

The formulation of curriculum philosophy of SMP-SMA BBS is relevent with the concepts offered by some experts that education should include aspects of cognitive, affective and psychomotor (Bloom et al., 1976); 'smart and good' (Lickona, 1992); thinking, acting, feeling (Gable, 1986); 'intelligence plus character" (Martin Luther King, 1948); "thought, feeling and behavior" (Jung, the Hall \& Lindzey, 1985). Similarly, McNeil (1996, p. 6) considers the importance of confluent education, i.e. education that combines affective aspects (emotion, attitude, values) and cognitive in the curriculum, which is characterized by: 1) participation, in which children participate actively discussing what would be learned and there is no compulsion in authoritarian and unilateral way, 2) integration, namely the interaction, interpenetration, the integration between thoughts, feelings and actions, 3) relevance, which is closely related to the lesson material and the basic necessities of childrenlife both emotionally and intellectually, 4) self, which is the principal object of the child is learning to be learned, 5) goal, namely that the social goal is to develop the individual as a whole in the context of human society. This kind of education is expected to show "a person who exhibits this quality, not only cognitive but also developed in aesthetic and moral ways, that is, a person who does good works and has good character" (McNeil, 1996, p. 5).

In the perspective of unity of science, this format of education will provide a solution to the dichotomy of, a dichotomy between religion and science. According to Nasution (2005, p. 22), historically, in classical times, in Islam there is no dichotomy between religion and science as it is now. Both of these sciences are taught to the students. At that time, according to Assegaf (2013, p. 3-4), people who seek the science called 'alim (singular) or the 'ulamá (plural) in an integrative sense, and not in a dichotomous sense. People called 'alim at that time was of the learned knowledge without separation between religion and science. 
In this context, Nasution (2005, p. 21-23) explains the existing education system at that time: childhood were given lessons in Arabic and read the Koran. After he grew up, he was given religious instruction that includes Tafsir, Hadits, Aqidah, Fiqh and others. In addition, they were also given arithmetic, writing and other subjects needed in everyday life. At the next level, there were students who deepen their knowledge about the religion and there were students who deepen their knowledge about sciences such as medicine, mathematics, natural science, and so on. The latter group also deepened their knowledge of philosophy. There was also group who deepen their knowledge of religion and science as well. As a result of this system, there are scholars such as Malik ibn Anas, Abu Hanifa and others in the science of figh, Wasil ibn Ata' al-'Ash'ari and others in the science of theology (kalam), the Muslim and Bukhari and others in the field of hadith. There are many other examples of scholars who deepen their knowledge in the field of religion. Moreover, there are many scholars in science and philosophy such as al-Kindi, al-Farabi, al-Razi and others. There were also scholars who deepen their knowledge in the field of religious and mundane knowledge at the same time, such as Ibn Sina (philosopher, physician and theologian), al-Ghazali (philosopher, mutakallimīn, jurist, Sufi) and Ibn Rushd (philosopher, jurist, Qadi, a doctor).

SMP-SMA Semesta BBS 2006 applies a national curriculum (KTSP) enriched by Semesta vision, known as the "national curriculum plus". Because KTSP as a basis in developing the curriculum, the curriculum concept model used in the Semesta is an eclectic of four models of curriculum concepts (Sanjaya, 2008, p. 130-131), namely: the humanistic curriculum, social reconstruction curriculum, systemic curriculum and academic curriculum (McNeil, 1996, p. 1). In this context, Print (1993, p. 56) states that "curriculum developers find themselves often aligning their positions with two or more curriculum conceptions". However, practically it is difficult to separate between one model concept to another. It means that almost no educational practice based solely on one model concept of curriculum. Generally, an eclectic concept model is adopted.

The emergence of four different models of curriculum concept is due to different philosophical bases, which by Ornstein and Hunkins (2009, p. 56) grouped into four, namely: perenialisme, essentialism, progressivism, and reconstructionism. From this philosophical foundation, it emerges the theory of education, namely: the theory of classical education, personalized education theory, the theory of interactional education and educational technology theory. From the theory of classical education, it arouses the concept of the model curriculum of academic subjects, from personalized education theory spawned a humanistic curriculum, and from education 
interactional theory, it leads to social reconstruction curriculum and from education technology theory, it bears technologist curriculum.

The following activities of internalizing moral values (self-discipline and responsibility), namely: creating the climate and culture, classroom learning, habituation outside the classroom, extra-curricular, guidance (rebberlik and sobbet), camping, can be classified in three forms of design, namely: (1) design that blends in integrating into all subjects, (2) habituation and (3) the creating a school climate and culture.

Fraenkel (1977, p. 1-2) states that "teaching is value-oriented enterprise". Value is something that does not stand alone. It is something that is attached to another reality. Value is important and valuable is attached to an object or activity, a fondness for the purpose or philosophy of life, beliefs about actions in accordance with fondness, the conception of which is expected to significantly affect the behavior (Fraenkel, 1977, p. 7).

In the perspective of internalization, the conditioning program is an effective way. This is because the value can not be taught but it can only be put into practice. In other words, the values should be familiarized in everyday life. Habituation is an effective method in the internalization of values (Zaenuddin et al, 1991, p. 106; Azizy, 2002, p. 146; Dewantara, 1962, p. 28). Al-Ghazali (Zaenuddin et. al, 1991, p. 106) also states that "if the child is taught to recognize what is good, be educated in that direction, surely he/she will grow well as a result of such positive habituation and will live happily here and the here after."

Creating climate and culture is an effective way in the internalization of discipline and responsibility. Because socio-psychologically the individual is greatly formed through imitation, identification, suggestion, sympathy, empathy (Gerungan, 1998, p. 10), therefore children who have potential of imitation, identification, suggestion, sympathy and empathy require exemplary of other people such as teachers, parents, and other adult (Ramayulis, 2005, p. 81). Latifah (2011) in her research showed that the ideals (modeling) has a positive contribution to the moral formation of children. Tafsir (1994, p. 143) states that students tend to emulate the educators.

Al-Nahlawy (1996, p. 262-263 ) also assertes that "every student will imitate educators and completely satisfied with the teachings given to them, so the ideal behavior expected of every studenyts". Madjid (2000, p. 95) also states that "education through modelling for children practically is more effective and more stable than oral education". Olim (2010, p. 151) states that the moral formation can be done through several stages, namely: (a) Preparing the foundation of noble character through aesthetic touches, (b) Learning by example (modeling), (c) Learning through habituation, (d) Development of knowledge. 
Based on the above models of internalization of value, Basourakos (1999, pp. 473-489) classifies the approaches to the internalization of values into two categories: 1) conventional moral pedagogy, 2) contextual moral pedagogy. The first approach, the moral values that are abstract and absolute are taught directly by the teacher (direct instruction) with example (modelling), whereas the second approach, the moral values are constructed and related to specific social contexts. In the context of SMP-SMA Semesta BBS, both approaches are used in internalizing discipline and responsibility, but the first approach is dominated through example, habituation; while the second approach is integrativelyundertakenin an active learning processin each subject in accordance with the structure of the existing subjects.

Sjarkawi (2011, p. 37-38) classifies approach of value education into two, namely: 1) processes that slightly include cognitive factors, which Frankena (1971) referred to as traditional moral education, or Blasi (1980) regarded as a 'irrational' moral education; and 2) a modern approach which Blasi (1980) called as a rational approach. SMP-SMA Semesta BBS are more dominated with the first approach than the latter one. The first approach that contains elements of indoctrination and less usage of reasoning process is undertaken because children need a set of qualities, behaviors, and dispositions (Socket, 1992, Johansson, 2011), to avoid moral relativism (Berreth \& Berman, 1997; Doyle, 1997; Fenstermacher, 2001).

The second approach is the modern approach which Blasi (1980) called as a rational approach because moral behavior is intrinsically rational response sourced and derived from the understanding and reasoning based on humanity and justice goals. The model is characterized by the use of the cognitive aspects of moral education, such as critical thinking, moral decision-making (DeVries, 1997; Lopez \& Lopez, 1998; Schuitema, Dam \& Veugelers, 2007, p. 1), problem-based learning, which gives an opportunity to students to move in small groups and give students opportunities for dialogue and interaction among students (Schuitema, Dam \& Veugelers, 2007).

Psychologically, the first approach that is cognitive approach (Sjarkawi), or traditional moral approach (Frankena), or irrational approach (Blasi) or conventional moral pedagogy (Basourakos), is based on the behavioristic psychology; while the second approach, that is modern approach (Syarkawi), or rational approach (Blasi), or contextual moral pedagogy (Basourakos)is based on cognitive psychology.

Based on the behavioristic psychology, internalization of values is conducted with indoctrination approach. According to this theory, learning relates to various aspects of stimulus-response and reinforcement. According to the behavioristic and associations, learning is a series of stimulus-response 
association between the conditioned, modified or created through reinforcement and rewards (Ornstein \& Hunkins, 2009, p. 101). In cognitive psychology, the internalization of values is undertaken with a modern approach, where cultivation of valuesis emphasized onthe existing moral judgment in children. Teacher or educator helps children in developing moral considerations.

Boarding system which historically can be traced from the education system implemented in pesantren has many advantages in internalizing moral values. Pesantren is the oldest form of Islamic education in Indonesia (Ridwan, 1993 [4], p. 104) and is one form of indigenous Indonesian culture (Saleh, 1982, p. 6). Most Islamic education have boarding where students reside in rooms provided for the study, sleep and various other activities. The type, size and quality of the rooms also vary in accordance with the conditions of the school.

At the boarding school system, the learning process tends to be more humanistic, religious and (Maksudin, 2013, p. 114). The non-dichotomic education format is built on the basis of Islam, because Islam does not recognize a dichotomy (Mas'ud, 2002, p. 17). Schools organized by educational boarding system have certain advantages (Maksudin, 2013, p. 106-107), among which are: 1) The number of students in the classroom are usually smaller than the existing classes in non boarding schools. It is intended to allows teachers to engage all students in learning and to actively engage with all students to interact directly in the classroom; 2) The quality of academic education and special skills to students is a top priority; 3) The resources available to the boarding school system, such as a library, theater facilities, sports facilities, local option is more adequate quality; 4) boarding school system has higher academic standards and this is a challenge for students; 5) Choice of subjects or skills in school with boarding system is more and varied and has a wider coverage; 6) Advisory boarding school system usually consist of the relevant experts.

Boarding-based school is more appreciative to the systems of time. In using the time in all forms of implementation, systems development and educational services are deeply performed with moral values. For example, the education system implemented in SMP Islam Abu Bakr Yogyakarta paid attention to the following matters: 1) student activities are guided by a mentor; 2) The closeness between students and tutors is always maintained. (3) A variety of student issues promptly identified and resolved; 4) Applied exemplary models provided by the supervisor; 5) Development of mental conducted specifically; 6) Speech, behavior and attitudes of students constantly monitored; 7) Positive tradition appropriately selected for students; 8) Cultivating values in the student community; 9) The formation 
of a good commitment among students to the tradition; 10) The student and mentor gives advice to each other about patience, truth and compassion; 11) The cultivation of common values such as honesty, tolerance, responsibility, compliance, self-directed observed and monitored continuously by the supervisor; 12) School activities scheduled for 24 hours in accordance with a prescribed program; 13) Any activities are governed by school rules (Maksudin, 2013, p. 106).

According to Maksudin (2013, p. 110), boarding-basedschool system emphasized the principles of self-reliance. This principle includes a variety of moral values depicted in the four personalities, namely: firstly, the person who regards life as growth and development. This means that the person sees life as a process to be a figure that is colored by the experiences of his/her choices which resulted in the growth or development. Therefore, this person is dare to take a risk or is responsible infacing various conflicts which he/she is aware of as a result ofa developmental process. In fact, he/she believes that life without a risk can prevent the process of self-development.Secondly, individuals have awareness of their identity and credentials. Personally,they can recognize and explain the values, as far as the values have become the top of theirtrue identity. Thirdly, the person is always frank and sensitive to the needs of others. He/she does not tear itself away with and avoid the people around him/her. He/she can clearly communicate a sense of empathy for others. Fourthly, the person has personality that illustrates a determination of personal consciousness. He/she felt a balance between heart and mind. $\mathrm{He} / \mathrm{she}$ has a sense of personal integrity andcan use the power of intuition, imagination and reasoning with balance.

\section{CONCLUSION}

The fact that thecurriculum of Junior-Senior High School (SMP-SMA) Semesta BBS Semarang-Indonesia is based on pesantren boarding system, further established that the pesantren, the oldest and typical of Islamic boarding schools has been widely adopted in Indonesia. Educational institution which first adopted the boarding system is madrassa, one of the Islamic educational institutions as well. Now, after realizing the many advantages, has expanded into public schools. The typical of boarding school curriculum of pesantren puts more emphasis on strengthening the affective aspects, because; 1) design that blends in integration with the curriculum design of all subjects in school, 2) the design through the development of self-habituation, 3) design through creating climate and culture, 4) constitute the hidden curriculum, 5) more "mutually adaptive". In the internalization of values, it is more dominated by transmission model rather than transaction and transformation model, 6) can be used as an eclectic systems, between 
constructivist-non-constructivist, the social-personal model, the informationprocessing model, the humanism-behavioral oriented. The main purpose of public schools adopting the boarding school system to be able to maintain and improve the quality of learners morals. Almost unheard of news there are fighting between madrassa students. Instead, almost every day there was news brawl between certain school student with a particular school even some members of the motorcycle gang, general status or former student of a public school instead of a madrasah or pesantren. However by adopting the boarding school system, learners can be monitored, productive and creative for almost 24 hours because they were in the neighborhood campusnya. Thus adopting a boarding school system can be a solution to overcome and reduce morale among students dekandensi Indonesia and even in other countries.

\section{BIBLIOGRAPHY}

Abdullah, M. Amin. (1998). Problem Epistemologis-Metodologis Pendidikan Islam, In Abdul Munir Mulkhan et al., Religiusitas Iptek. Yogjakarta: Pustaka Pelajar.

Al-Abrasy, Mohammad Athiyah. (t.t.). Al-Tarbiyyah al-Islamiyah. Beirut: Dar alFikr.

Alwi, Hasan. (2005). Kamus Besar Bahasa Indonesia. Jakarta: Badan Pengembangan dan Pembinaan Bahasa.

Aly, Abdullah. (2011). Pendidikan Islam Multikultural di Pesantren: Telaah terhadap Kurikulum Pondok Pesantren Modern Islam Assalam. Yogjakarta: Pustaka Pelajar.

Amin, A. (1967). Kitäb al-Akbläq, Kairo: an-Nahdlah al-Misriyah.

Aqib, Zainal \& Sujak. (2011). Panduan dan Aplikasi Pendidikan Karakter untuk $S D / M I, S M P / M T s, S M A / M A$, SMK/MAK. Bandung: Yrama Widya.

Assegaf, Abd. Rachman. (2013). Aliran Pendidikan Islam: Hadlarah Keilmuan Tokoh Klasik sampai Modern. Jakarta: Rajawali Pers.

Azizy, A. Qodry. (2002). Pendidikan (Agama) untuk Membangun Etika Sosial: Mendidik Anak Sukses Masa Depan, Pandai dan Bermanfaat. Semarang: Aneka Ilmu.

Azra, Azyumardi. (2002). Paradigma Baru Pendidikan Nasional: Rekonstruksi dan Demokratisasi. Jakarta: Kompas.

Azra, Azyumardi. (2005). Pendidikan Islam: Tradisi dan Modernisasi Menuju Milenium Baru. Jakarta: Logos.

Basourakos, J. (1999). Moral Voices and Moral Choices: Canadian Drama and Moral Pedagogy. Journal of Moral Education, 28(4).

Berret, D. \& Berman, S. (1997). "The Moral Dimension of Schools". Educational Leadership. 54, (8), 24-27. 
Blasi, A. (1980). "Bringing Moral Cognition and Moral Action: A Critical Review of The Literature", Psychological Bulletin, 88, (1), 1-45.

Bloom, Benjamin S.; Krathwohl, David R.; Masia, Bertram B. (1976). Taxonomy of Educational Objectives: Book 2 Affective Domain. London: Longman.

Buchori, Mochtar. (1992). Posisi dan Fungsi Pendidikan Agama Islam dalam Kurikulum Perguruan Tinggi Umum. Proceedings of the Seminar Nasional in IKIP Malang.

Creasy. (2010). What is Character? In Educational Policy, 3(12).

Damopolii, Muljono. (2011). Pesantren Modern IMMIM Pencetak Muslim Modern. Jakarta: Rajawali Pers.

Davidson, Matthew \& Lickona, Thomas. (2007). Integrating Performance Character and Moral Character in Schools. Retrieved from http://www.nais.org/publications/ismagazinearticle.cfm?Itemnaumbe $\underline{\mathrm{r}=149286 \& \text { sn.ItemNumber }=145958}$

DeVries, R. (1997). Piaget's Social Theory. Educational Researcher. 26(2), pp. 417.

Dewantara, Ki Hadjar. (1962). Pendidikan. Jogjakarta: Madjelis Luhur Persatuan Taman Siswa.

Dolph, Katie \& Lycan, Angela. (2008). Moral Reasoning: A Necessary Standard of Learning in Today's Classroom. Journal of Cross-Disciplinary Perspectives in Education. 1(1), pp. 13-19.

Doyle, D.P. (1997). Education and Character: A Conservative View. Phi Delta Kappan. 78(6), pp. 440-443.

Durkheim, E. (1990). Moral Education. Terj Lukas Ginting. Jakarta: Erlangga. Fenstermacher, G.D. (2001). On the Concept of Manner and Its Visibility in Teaching Practice. Journal of Curriculum Studies. 33(6), pp. 639-653.

Fraenkel, Jack R. (1977). How to Teach about V alue. London: Prentice-Hall, Inc.

Frankena, W.K. (1971). "Moral Education, Philosophic View". in Lee C. Deighton (Ed.). The Encyclopedia of Education, (Vols. 6). New York: The Mcmillan Company and The Press, pp. 394-398.

Freire, Paulo. (1995). Pendidikan kaum Tertindas (Pedagogy of The Oppressed), terj. Tim Redaksi, Jakarta: LP3ES.

Fuaduddin \& Bisri, Hasan. (Ed.). (1999). Dinamika Pemikiran Islam di Perguruan Tinggi. Jakarta: Logos.

Gable, Robert K. (1986). Instrument Development in the Affective Domain. Boston: Kluwer-Nijhoff Pub.

Gerungan, W.A. (1998). Psikologi Sosial. Jakarta: Rajawali Pers.

Al-Ghazali, M.H.A. (n.d). Ibyä' 'Ulümiddin, III, Bairut: Darul Fikr. 
Goods, C.V. (Ed.). (1945). Dictionary of Education. New York: McGraw-Hill Book Company Inc.

Hadjar, Ibnu. (2006, Marc 4). Evaluasi Hasil Belajar Afektif Pendidikan Agama: Problem Konseptual dan Pengukuran, Inauguration speech of professor in the Science of Educational Evaluation presented at Tarbiyah Faculty of IAIN Walisongo, Semarang-Indonesia.

Hasan, Said Hamid et al. (2010). Pengembangan Pendidikan Budaya dan Karakter Bangsa. Bahan Pelatihan Penguatan Metodologi Pembelajaran Berdasarkan Nilai-nilai Budaya untuk. Membentuk Daya Saing dan Karakter Bangsa. Jakarta: Puskur Balitbang Kemendiknas.

Hufad, A. \& Sauri, S. (2010). Pendidikan Karakter Berbasis Nilai: Antara Makna, Urgensi dan Praksis. In Potret Profesionalisme Guru dalam Membangun Karakter Bangsa: Pengalaman Indonesia dan Malaysia. Bandung: Universitas Pendidikan Indonesia.

Johansson, E. (2011). Practices for Teaching Moral Values in the Early Years: a Call for a Pedagogy of Participation. Education, Citizenship and Social Justice. 6(2), 109-124.

Kohlberg, L. (1977). The Cognitive-Developmental Approach to Moral Education. Boston: Allyn and Bacon Inc.

Langgulung, Hasan. (1989). Manusia dan Pendidikan: Suatu Analisa Psikologi dan Pendidikan. Jakarta: Pustaka al-Husna.

Latifah, Umi, Siti. (2011). Pola-pola Metode Keteladanan untuk Penanaman Akblak Peserta Didik di SD Negeri Pengkol Godean Sleman Yogjakarta, (Research Report) Yogyakarta: Tarbiyah Faculty of UIN Sunan Kalijaga.

Lickona, T. (1992). Educating for Character: How Our Schools Can Teach Respect and Responsibilty. New York: Bantam Book.

Lickona, T. (2013). Pendidikan Karakter: Panduan lengkap Mendidik Anak Menjadi Pintar dan Baik. Terj. Lita S., Bandung: Nusa Media.

Lopez, B.G., \& Lopez, R.G. (1998). The Improvement of Moral Development through an Increase in Reflection: a Training Programme. Journal of Moral Eucation, 27(2), pp. 225-241.

Madjid, Nurcholish. (2000). Pengantar. In A. Malik Fadjar. Reorientasi Pendidikan Islam. Jakarta: Fajar Dunia.

Maksudin. (2013). Pendidikan Karakter Non-Dikotomik. Yogyakarta: Pustaka Pelajar.

Mas'ud, Abdurrahman. (2002). Menggagas Format Pendidikan Non Dikotomik: Humanisme Religius sebagai Paradigma Pendidikan Islam. Yogjakarta: Gama Media.

McNeil, J. D. (1996). Contemporary Curriculum in Thought and Action. Los Angeles: John Wiley \& Sons, Inc.

Megawangi, R. (2007). Semua Berakar pada Karakter. Jakarta: FE-UI. 
Miskawayh, Ibn. (1999). Menuju Kesempurnaan Akhlāq: Buku dasar Pertama tentang Filsafat Etika. Terj. Helmi Hidayat. Bandung: Mizan.

Muhaimin. (2009). Pengembangan Kurikulum Pendidikan Agama Islam di Sekolah, Madrasab dan Perguruan Tinggi. Jakarta: Rajawali Pers.

Muslich, Masnur. (2011). Pendidikan Karakter: Menjawab Tantangan Krisis Multidimensional. Jakarta: Bumi Aksara.

Nasution, Harun. (1995). Islam Rasional: Gagasan dan Pemikiran. Bandung: Mizan.

Nasution, Harun. (2005). Sekitar Masalah Pengembangan IAIN menjadi UIN. In Munzir Hitami et al. (Ed.). Rekonstruksi Ilmu di Alaf Baru: UIN Suska Riau Menuju Universitas Terkemuka di Asia Tenggara. Pekanbaru: Suska Press.

Noddings, N. (2010). Moral Education and Caring, Journal Theory and Research in Education, 8(2), pp. 145-151.

Nurchaili. (2010). Membentuk Karakter Siswa melalui Keteladanan Guru. In Jurnal Pendidikan dan Kebudayaan. 16(Special Edition III), Balitbang Kementerian Pendidikan Nasional.

Oladipo, S.E. (2009). Moral Education of the Child: Whose Responsibility?, J Sec Sei, 20(2), pp. 149-156.

Olim, Ayi. (2010). Mencari Metode Pendidikan Karakter untuk PAUD: Belajar Berbasis Layanan (Service Learning). In Dadang Sunendar et al. Teacher Education in Developing National Characters and Cultures. Proceedings The 4th International Conference on Teacher Education, Jointly Organized by Universitas Pendidikan Indonesia (UPI) Indonesia and Universiti Pendidikan Sultan Idris (UPSI) Malaysia.

Ornstein, Allan C. \& Hunkins, Francis P. (2009). Curriculum: Foundation, Principle and Issues. New York: Pearson.

Prabowo, Agung \& Sidi, Pramono. (2010). Memahat Karakter Melalui Pembelajaran Matematika. In Dadang Sunendar et al. Teacher Education in Developing National Characters and Cultures. Proceedings The 4th International Conference on Teacher Education, Jointly Organized by Universitas Pendidikan Indonesia (UPI) Indonesia and Universiti Pendidikan Sultan Idris (UPSI) Malaysia.

Print, Murray. (1993). Curriculum Development and Design. Sydney: Allen \& Unwin Pty Ltd.

Ramayulis. (2005). Metodologi Pendidikan Agama Islam. Jakarta: Kalam Mulia.

Ridwan, Kafrawi (Ed.). (1993). Ensiklopedi Islam Jilid 4. Jakarta: PT Ichtiar Baru van Houve.

Saleh, Abdurrahman et al. (1982). Pedoman Pembinaan Pondok Pesantren. Jakarta: Binbaga Islam Depag RI.

Sanjaya, Wina. (2008). Kurikulum dan Pembelajaran. Jakarta: Kencana. 
Schuitema, J. \& Dam, G.T. \& Veugelers, W. (2007). Teaching Strategies for Moral Education: a review, J. Curriculum Studies. pp. 1-21,First Article.

Shochib, Moh. (2010). Pola Asub Orang Tua dalam Membantu Anak Mengembangkan Disiplin Diri. Jakarta: Rineka Cipta.

Sjarkawi. (2011). Pembentukan Kepribadian Anak: Peran Moral, Intelektual, Emosional dan Sosial sebagai Wujud Integritas Membangun Jati Diri. Jakarta: Bumi Aksara.

Sukmadinata, Nana Syaodih, (2011). Pengembangan Kurikulum: Teori dan Praktek. Bandung: Remaja Rosdakarya.

Supriadi, Dedi. (1998). Mengangkat Citra dan Martabat Guru. Yogjakarta: Adicita Karya Nusa.

Supriyatna, E. (2010). Pendidikan Sejarah yang Berbasis Nilai-nilai Religi dan Budaya Lokal banten untuk Menumbuhkan Karakter Siswa. In Dadang Sunendar et al. Teacher Education in Developing National Characters and Cultures. Proceedings The 4th International Conference on Teacher Education, Jointly Organized by Universitas Pendidikan Indonesia (UPI) Indonesia and Universiti Pendidikan Sultan Idris (UPSI) Malaysia.

Syauqi, Ahmad. (n.d.). Asy-Syanqiyyāt. Beirut: Dar al-Kutub al-'Ilmiyyah.

Syukur, Amin. (2000). Pengantar Studi Agama. Semarang: Bima Sejati.

Tafsir, Ahmad. (1994). Ilmu Pendidikan dalam Perspektif Islam. Bandung: Remaja Rosdakarya.

Zaenuddin et al. (1992). Seluk Beluk Pendidikan Versi al-Ghazali. Jakarta: Rineka Cipta.

Zubaedi. (2011). Desain Pendidikan Karakter: Konsepsi dan Aplikasinya dalam Lembaga Pendidikan. Jakarta: Prenada Media.

Zubaedi. (2009). Memperkuat Dimensi Pendidikan Moral: In Mawardi Lubis. Evaluasi Pendidikan Nilai. Yogjakarta: Pustaka Pelajar. 